\title{
Nitrogen Fertilization and Rhizobacteria in the Control of Meloidogyne javanica in Common Bean Plants
}

\author{
Bruna Hanielle Carneiro dos Santos ${ }^{1}$, Regina Cássia Ferreira Ribeiro ${ }^{1}$, Adelica Aparecida Xavier ${ }^{1}$, \\ José Augusto Santos Neto ${ }^{1} \&$ Edson Hiydu Mizobutsi ${ }^{1}$ \\ ${ }^{1}$ State University of Montes Claros, Janaúba, Brazil \\ Correspondence: Bruna Hanielle Carneiro dos Santos, State University of Montes Claros, Janaúba, Brazil. \\ E-mail: bruninha_agro@hotmail.com
}

Received: August 29, 2018

doi:10.5539/jas.v11n1p430

\author{
Accepted: October 9, $2018 \quad$ Online Published: December 15, 2018 \\ URL: https://doi.org/10.5539/jas.v11n1p430
}

\begin{abstract}
The effects of treating seeds of the common bean with rhizobacteria before sowing associated with different nitrogen $(\mathrm{N})$ doses on the control of the nematode Meloidogyne javanica was evaluated. The assay was carried out in a greenhouse in random blocks, with a factorial arrangement of $5 \times 5+1$ : five $\mathrm{N}$ doses $(0,25,50,100$, and $200 \mathrm{~kg} / \mathrm{ha}$ ); five isolates: Bacillus pumilus (1, 60 and 76), Bacillus subtilis.-34, Bacillus sp.-36, and one control treatment. The plants were inoculated with 3,000 nematode eggs/pot. After 60 days the assay was evaluated. In the absence of N, B. pumilus-60 promoted a reduction of more than $50 \%$ in the number of galls and egg masses compared to the control. B. pumilus (1 and 76) and Bacillus sp.-36 reduced the number of galls in combination with increased $\mathrm{N}$ doses. Treatment of seeds with Bacillus in combination with $\mathrm{N}$ fertilization contributed to a reduction in the number of galls and nematode egg masses. B. pumilus (60 and 76) reduced the number of galls and egg masses in the absence of $\mathrm{N}$, indicating a nematicidal effect. The treatments had no effect on the number of second-stage juveniles, eggs, or the plant parameters.
\end{abstract}

Keywords: root-knot nematode, biological control, Phaseolus vulgaris

\section{Introduction}

The common bean (Phaseolus vulgaris L.) has great socio-economic importance in Brazil, it is one of the main components of the diet due to its high protein content (Soares et al., 2006). The crop is cultivated throughout Brazil because good adaptation to a range of edaphoclimatic conditions. The main producing regions are the States of Paraná, Bahia, Minas Gerais, Goiás and São Paulo (IBGE, 2014).

The nematode specie Meloidogyne javanica (Treub) Chitwood is one of the main causes of reductions in bean crop yields, especially in regions routinely subject to high temperatures that increase environmental stress and affect plant tolerance to the nematode (Pedrosa, 2000). The losses in common bean crops caused by parasitism by M. incognita (Kofoid; White) Chitwood and M. javanica may reach up to 90\% (Agudelo, 1980).

The standard measures to control Meloidogyne spp. in common bean crops are crop rotation, fallow periods, and use of resistant varieties. However, the strategy of using high resistance varieties is limited, there are no available genetic materials for farmers (Pedrosa et al., 2000; Simão et al., 2005). Moreover, crop rotation and fallow periods are difficult to establish. The farmers prefer to cultivate crops during the three annual seasons in irrigated areas, which causes an increased nematode population density in these regions.

Nitrogen fertilizers are extremely important for plant development. The incorporation of some fertilizers into the soil can have a suppressive effect on nematode populations; for example, urease activity can convert urea to ammonia, which is toxic to nematodes (Sidiqqui et al., 2001).

The treatment of seeds with rhizobacteria particularly Bacillus species, has produced encouraging results for the control of many soil pathogens, including root-knot nematodes (Meloidogyne spp.) (Ludwig et al., 2013). Numerous mechanisms are involved in the nematode control by rhizobacteria, such as alteration of root exudates and the consequent limitation of nematode penetration in the roots (Lian et al., 2007), reduction of juvenile hatching (Campos et al., 2006), production of enzymes and toxic compounds, and the induction of systemic resistance in the host plant (Oostendorp \& Sikora, 1990). In addition to acting as a biological control, rhizobacteria may also promote plant growth by synthesizing growth regulators such as indole acetic acid (IAA), 
gibberellins, and cytokines by biological nitrogen fixation or by solubilizing inorganic phosphates present in the soil.

A few studies have shown that a combined treatment with rhizobacteria and nitrogen fertilizer can improve plant development and crop yield (Khan et al., 2013). Nevertheless, there is no information on how such combinations affect nematode populations in common bean crops. Therefore, the aim of the present work was to evaluate the combination of treating seeds with five rhizobacterial isolates and the applying different doses of a nitrogen fertilizer for the control of M. javanica.

\section{Material and Methods}

The work was carried out in the State University of Montes Claros/UNIMONTES-Janaúba Campus. Five rhizobacterial isolates from a bacterial library available in the Laboratory of Phytopathology were tested. The selected isolates were previously shown to be promising candidates for use in the control of $M$. javanica in banana trees (Ribeiro et al., 2012); the isolates used were: Bacillus pumilus-1, B. pumilus-60, B. pumilus-76, B. subtilis-34, and Bacillus sp.-36 (Ribeiro et al., 2012). The isolates were identified by the fatty acid profile test by gas chromatography (Sanhueza \& Melo, 2007) in the Environmental Microbiology laboratory of the National Center for Environmental Research of the Brazilian Agricultural Research Corporation (Embrapa).

\subsection{Bacterial Inoculum and Seed Treatment}

Bacteria maintained in TSA (Tryptic-Soy-Agar) medium at $-4{ }^{\circ} \mathrm{C}$ were transferred to fresh TSA medium and incubated at $28{ }^{\circ} \mathrm{C}$ for 48 hours. In a flow chamber, the bacteria were resuspended in sterile saline solution $(0.85 \% \mathrm{NaCl})$, transferred to centrifuge tubes, and centrifuged at $10,000 \mathrm{rpm}$ for 10 minutes. The supernatant was discarded and $3 \mathrm{~mL}$ saline solution $(0.85 \% \mathrm{NaCl})$ were added to the pellet. The resulting suspension was agitated and calibrated in a spectrophotometer to an optical density of OD540 $=0.5$ absorbance (approximately $10^{8} \mathrm{CFU}$ ). This quantification was determined by estimating bacterial concentrations in the medium by serial dilution and counting in plates containing TSA medium.

The rhizobacterial inoculum was prepared by the addition of $15 \mathrm{~mL}$ suspension of each Bacillus isolate to

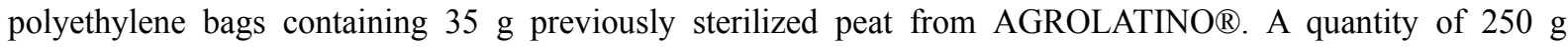
inoculum per $50 \mathrm{~kg}$ common bean seeds were used. A $10 \%$ sucrose solution was added to the inoculum in order to improve its fixation to the seeds (Xavier et al., 2011).

Samples ( $100 \mathrm{~g})$ of common bean type carioca cultivar 'Pérola' were sterilized with $1 \%$ sodium hypochlorite for 10 min, washed four times in sterile distilled water, and spread on absorbing paper to dry in a flow chamber for 2 hours (Chun et al., 1997). The seeds were subsequently inoculated with one of the bacterial isolates and kept at room temperature for 24 hours.

\subsection{Experimental Design, Data Collection and Statistical Analysis}

The M. javanica inoculum was prepared from a pure population of the nematode maintained in tomato plants cultivar 'Kada' grown in pots containing previously autoclaved sandy soil. M. javanica eggs were extracted from the roots as described by Hussey and Barker (1973) and modified by Bonetti and Ferraz (1981).

The assay was carried out in a greenhouse using the randomized block design with a factorial scheme of $5 \times 5+$ 1: five nitrogen doses $(0,25,50,100$ and $200 \mathrm{~kg} / \mathrm{ha})$ in the form of urea, five rhizobacterial isolates $(B$. pumilus-1, B. subtilis-34, Bacillus sp.-36, B. pumilus-60 and B. pumilus-76) added to common bean seeds, and one control treatment (untreated seeds cultivated in soils infested with M. javanica). Each treatment was performed 10 replications and the experimental unit consisted of a pot containing one common bean plant.

The experiment was conducted in $4 \mathrm{~L}$ pots filled with sandy soil fluvisol with the following composition: 9 $\mathrm{dag} / \mathrm{kg}$ clay, $88 \mathrm{dag} / \mathrm{kg}$ sand, $8 \mathrm{dag} / \mathrm{kg}$ silt, $0.2 \mathrm{dag} / \mathrm{kg}$ organic matter, $\mathrm{pH} 7.3,53.7 \mathrm{mg} / \mathrm{dm} \mathrm{P;} 70 \mathrm{mg} / \mathrm{dm} \mathrm{K} ; 1.6$ $\mathrm{cmolc} / \mathrm{dm} \mathrm{Ca} ; 0.5 \mathrm{cmolc} / \mathrm{dm} \mathrm{Mg}$; and $84 \%$ base saturation. Five common bean seeds were sown in each pot and, after germination, thinned to one plant per pot. Twenty days after sowing, $3 \mathrm{~mL}$ of an aqueous suspension containing 3,000 M. javanica eggs were added to three holes surrounding the plants.

Based on the chemical analysis of the soil, and taking into account the recommendations for common bean crops (Ribeiro et al., 1999), a $100 \mathrm{mg} / \mathrm{dm}^{-3} \mathrm{P}_{2} \mathrm{O}_{5}$ with single superphosphate as the source and $0.5 \mathrm{mg} / \mathrm{dm}^{-3}$ boron with boric acid as the source when the beans were sown was applied. The nitrogen dose treatments as solutions at 15 , 30 , and 45 days after seed germination were applied. Irrigation was performed daily, keeping the soil constantly moist. 
Sixty days after nematode inoculation, the following characteristics were evaluated: root weight, plant weight, number of leaves, and fresh and dry weight of the aerial part. For dry weight determination, the plants were dried in a growth chamber under forced ventilation at $65^{\circ} \mathrm{C}$ to a constant weight.

In order to evaluate damage and nematode populations, plant roots were harvested, washed, weighed, and stained with floxin B (15 mg/L for $20 \mathrm{~min})$ to enable gall and egg masses counting (Taylor \& Sasser, 1978). After extraction according to the method of Hussey and Barker (1973) modified by Bonetti and Ferraz (1981), the number of eggs per root were quantified using a Peters chamber under an optical microscope. The number of second-stage juveniles was determined after removal of $100 \mathrm{~cm}^{3}$ soil from the pots; juvenile extraction was carried out using the method described by Jenkins (1964), followed by counting on a Peters chamber under an optical microscope.

The data were subjected to an analysis of variance and the means of the bacterial concentration were compared using the Scott-Knott test at a 5\% significance level. Nitrogen doses were adjusted to regression models using the statistical software SISVAR (Ferreira, 2011). The means of the treatments were compared to the control using Dunnett's test at a 5\% significance level using the statistical software SAS (SAS Institute, 2000).

\section{Results}

A significant reduction in the number of egg masses and galls per root was identified between plants subjected to the combined treatments (rhizobacteria $\times$ urea doses) compared with the control (Dunnett's test, $p<0.05$ ). The largest reductions in number of egg masses in comparison to controls were observed in the B. pumilus-60/0 N (54.68\%), B. subtilis-34/25 kg/ha urea (62.50\%), B. pumilus-1/50 kg/ha urea $(66.8 \%)$, B. subtilis-34/100 kg/ha urea $(84.6 \%)$, and $B$. pumilus $-1 / 200 \mathrm{~kg} / \mathrm{ha}$ urea $(83.17 \%)$. The greatest reductions in number of galls compared to the control were found for B. pumilus-60/0 N (57.0\%) and Bacillus sp.-36/25 kg/ha urea (69.04\%). At 50, 100, and $200 \mathrm{~kg} / \mathrm{ha}$ urea, the number of egg masses and galls were lower than in the controls in treatments with each isolate (Table 1).

Table 1. Number of Meloidogyne javanica egg masses and galls per root of common bean plants after inoculation of the seeds with rhizobacterial isolates and the addition of nitrogen doses to the soil, local and year

\begin{tabular}{|c|c|c|c|c|c|c|c|c|c|c|}
\hline \multirow{3}{*}{ Isolates } & \multicolumn{10}{|c|}{ Doses kg/ha } \\
\hline & \multicolumn{5}{|c|}{ Egg masses } & \multicolumn{5}{|c|}{ Galls } \\
\hline & 0 & 25 & 50 & 100 & 200 & 0 & 25 & 50 & 100 & 200 \\
\hline B. pumilus -60 & $37.7 \mathrm{a}^{\mathrm{yz}}$ & $38.0 \mathrm{a}^{\mathrm{y}}$ & $28.3 \mathrm{a}^{\mathrm{y}}$ & $35.1 \mathrm{a}^{\mathrm{y}}$ & $15.4 \mathrm{a}^{\mathrm{y}}$ & $7.3 \mathrm{a}^{\mathrm{y}}$ & $6.3 \mathrm{a}^{\mathrm{y}}$ & $6.0 \mathrm{a}^{*}$ & $7.0 \mathrm{~b}^{\mathrm{y}}$ & $5.2 \mathrm{a}^{\mathrm{y}}$ \\
\hline B. pumilus-76 & $43.6 \mathrm{a}^{\mathrm{y}}$ & $52.2 \mathrm{~b}$ & $49.5 \mathrm{a}$ & $34.0 \mathrm{a}^{\mathrm{y}}$ & $16.5 \mathrm{a}^{\mathrm{y}}$ & $7.7 \mathrm{a}^{\mathrm{y}}$ & $5.8 \mathrm{a}^{\mathrm{y}}$ & $4.0 \mathrm{a}^{*}$ & $2.6 \mathrm{a}^{\mathrm{y}}$ & $4.7 \mathrm{a}^{\mathrm{y}}$ \\
\hline Bacillus sp.-36 & $49.2 \mathrm{a}$ & $78.1 \mathrm{~b}$ & $44.6 \mathrm{a}$ & $34.5 \mathrm{a}^{\mathrm{y}}$ & $20.0 \mathrm{a}^{\mathrm{y}}$ & $9.0 \mathrm{a}^{\mathrm{y}}$ & $5.2 \mathrm{a}^{\mathrm{y}}$ & $8.8 \mathrm{a}^{*}$ & $5.2 \mathrm{~b}^{\mathrm{y}}$ & $4.2 \mathrm{a}^{\mathrm{y}}$ \\
\hline B. subtilis-34 & $53.3 \mathrm{a}$ & $31.2 \mathrm{a}^{\mathrm{y}}$ & $28.7 \mathrm{a}^{\mathrm{y}}$ & $12.8 \mathrm{a}^{\mathrm{y}}$ & $19.1 \mathrm{a}^{\mathrm{y}}$ & $11.0 \mathrm{a}$ & $11.0 \mathrm{~b}$ & $6.1 \mathrm{a}^{\mathrm{y}}$ & $7.3 b^{y}$ & $3.0 \mathrm{a}^{\mathrm{y}}$ \\
\hline B. pumillus -1 & $69.8 \mathrm{a}$ & $57.6 \mathrm{~b}$ & $27.6 \mathrm{a}^{\mathrm{y}}$ & $20.3 \mathrm{a}^{\mathrm{y}}$ & $14.0 \mathrm{a}^{\mathrm{y}}$ & $11.8 \mathrm{a}$ & $11.5 \mathrm{~b}$ & $5.5 \mathrm{a}^{\mathrm{y}}$ & $3.1 \mathrm{a}^{\mathrm{y}}$ & $3.3 \mathrm{a}^{\mathrm{y}}$ \\
\hline $\mathrm{VC}$ & 68.1 & & & & & 65.5 & & & & \\
\hline Control & 83.2 & & & & & 17.0 & & & & \\
\hline
\end{tabular}

Note. ${ }^{y}$ Statistical differences to the control according to the Dunnett's test at a 5\% significance level.

${ }^{z}$ Means followed by the same lowercase letters on the column do not significantly differ between each other according to the Scott-Knott test at a 5\% significance level.

There was no significant effect of rhizobacterial inoculation or application of urea in comparison with the control regarding numbers of second stage juveniles $/ 100 \mathrm{~cm}^{3}$ soil, or number of $M$. javanica eggs on the roots of the plants.

Significant interactions between the treatment with rhizobacterial isolates and nitrogen doses with regard to the number of egg masses and the number of galls $(\mathrm{p}<0.05)$ were observed. At $25 \mathrm{~kg} / \mathrm{ha}$ urea, the isolates $B$. pumilus-60 and B. subtilis-34 were the most effective at decreasing the number of M. javanica egg masses (Table 1). At $25 \mathrm{~kg} / \mathrm{ha}$ urea, the greatest reduction in gall number was promoted by isolates $B$. pumilus $-60, B$. pumilus-76, and Bacillus sp.-36. At $100 \mathrm{~kg} / \mathrm{ha}$ urea, the most effective isolates for control of M. javanica were $B$. pumilus-76 and B. pumilus-1. None urea application and the doses of $50 \mathrm{~kg} / \mathrm{ha}$ and $200 \mathrm{~kg} / \mathrm{ha}$ urea, isolates showed no differences for the tested endpoints (Table 1). 
Regression analyses revealed that increasing the $\mathrm{N}$ dose, together with application of isolates B. pumilus-1, B. subtilis-34, Bacillus sp.-36, or B. pumilus-76 caused a linear reduction in the number of $M$. javanica egg masses (Figure 1). The same effect was observed for isolates B. pumilus-1, Bacillus sp.-36, and B. pumilus-76 with regard with the number of galls per root (Figure 2).

The treatments (bacterial isolates and urea) had no significant effect on the tested variables when applied individually; or when they were applied together with respect to the numbers of $M$. javanica eggs, second stage juveniles, or vegetative characteristics such as height, fresh and dry weight of the aerial parts, root weight and leaf number (data not shown).
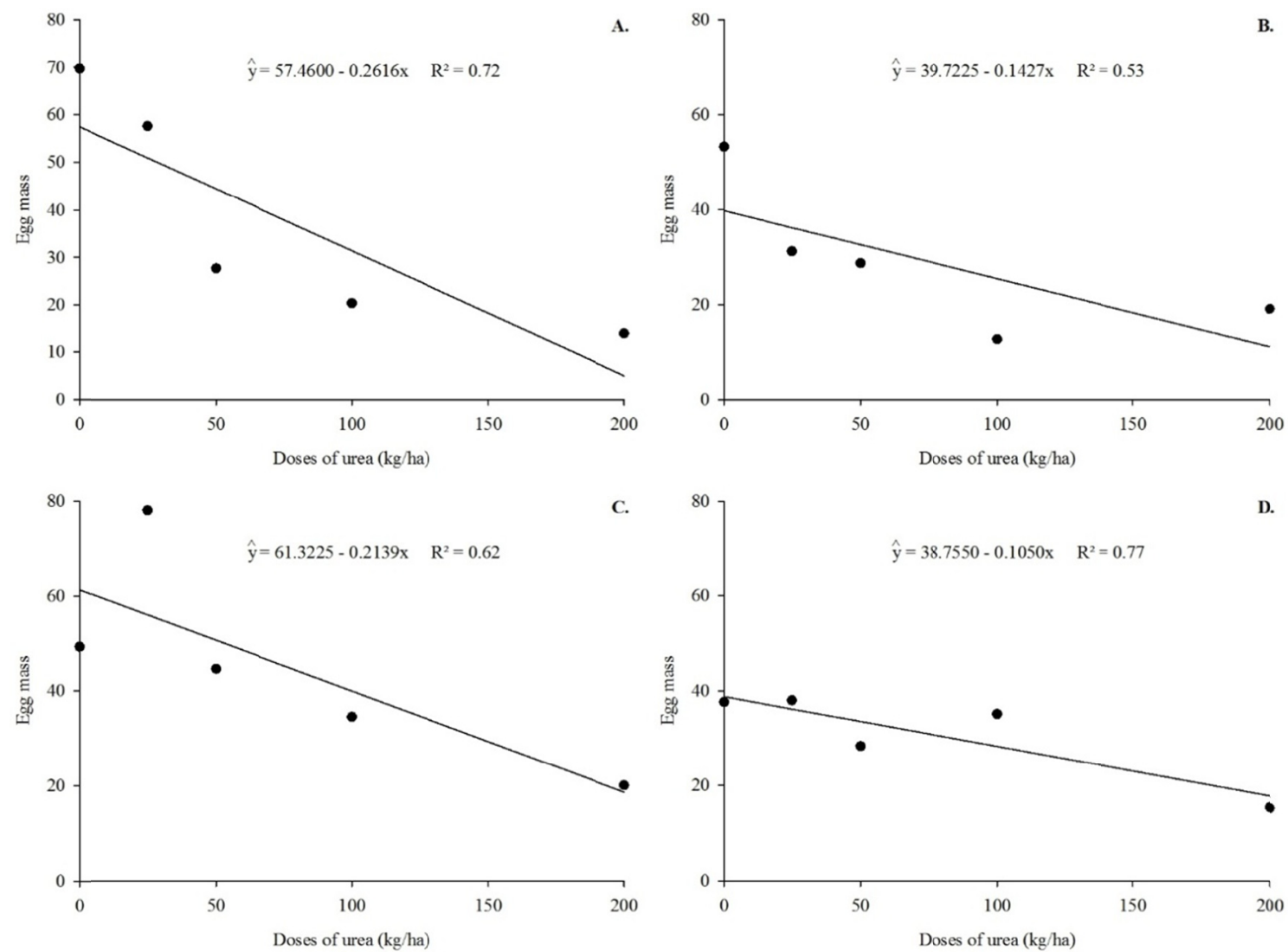

Figure 1. Number of Meloidogyne javanica egg masses per root of common bean plants after inoculation of the seeds with rhizobacterial isolates and the addition of nitrogen doses to the soil, Janaúba, 2018. (A) Bacillus pumilus-1; (B) Bacillus subtilis-34; (C) Bacillus sp-36; (D) Bacillus pumilus-76 

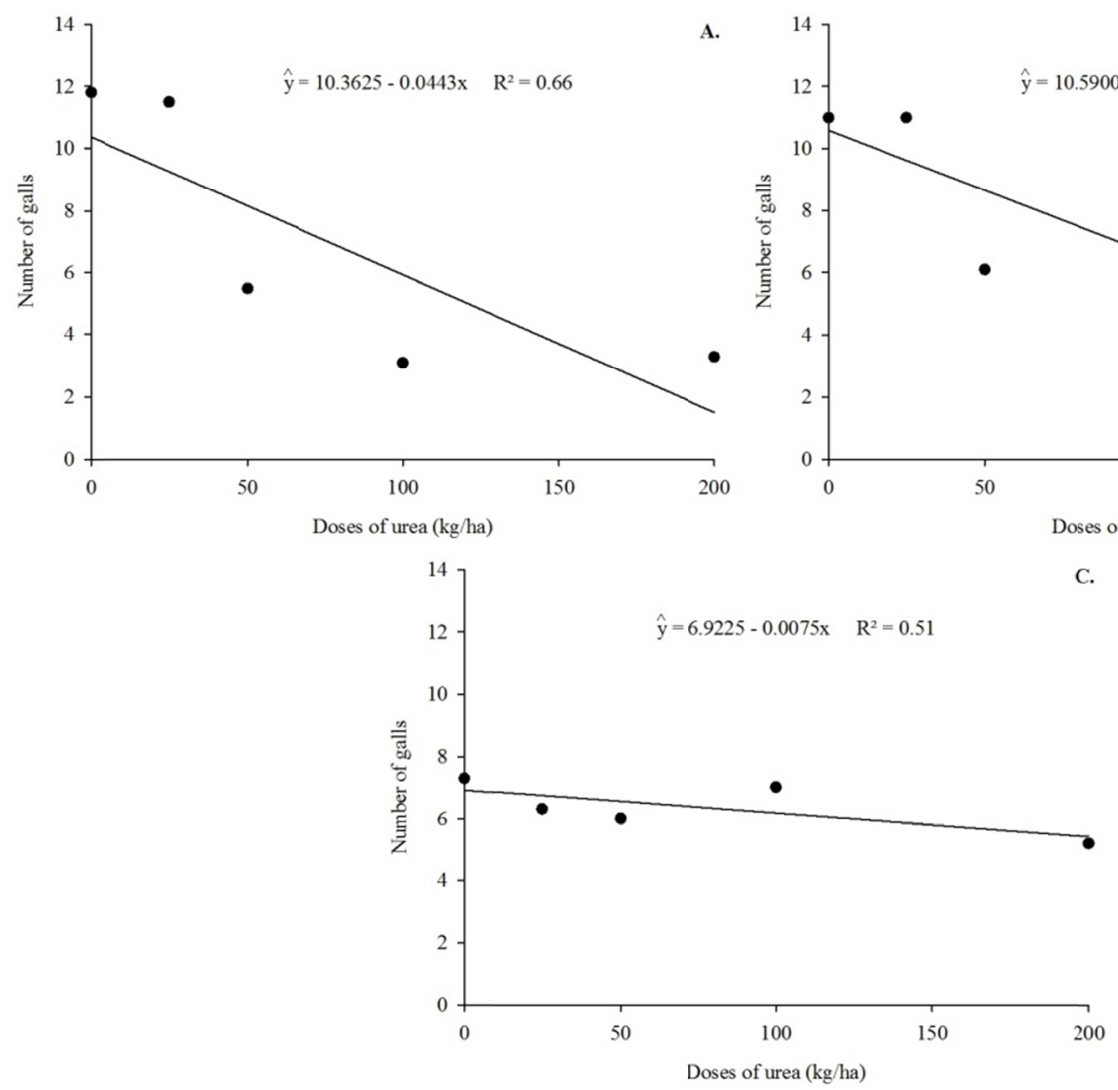

B.

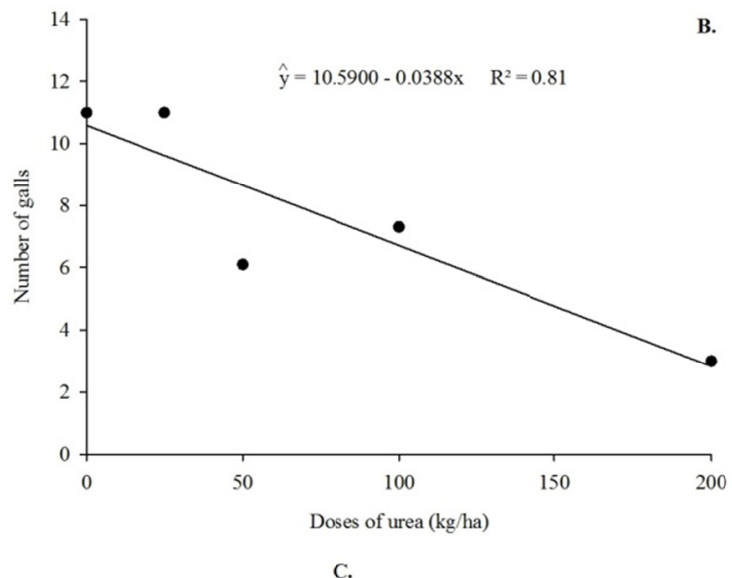

Figure 2. Number of Meloidogyne javanica egg masses and galls per root of common bean plants after inoculation of the seeds with rhizobacterial isolates and the addition of nitrogen doses to the soil, Janaúba, 2018.

(A) Bacillus pumilus-1; (B) Bacillus sp-36; (C) Bacillus pumilus-76

\section{Discussion}

The present work revealed that treatment of common bean seeds with rhizobacterial isolates could be effective in reducing the number of galls and egg masses in the presence of $\mathrm{N}$. The results varied among rhizobacterial isolates and nitrogen doses applied (Table 1). Previous studies have similarly shown that treatment of seeds can reduce infestation with Meloidogyne species (Corrêa et al., 2012).

Many reports have been demonstrated that organisms inoculated directly on the seeds are better able to colonize the plant roots, an important factor for a successful biological control (Dawar et al., 2008; Naue et al., 2014). The processes of seed germination and seedling growth are accompanied by the release of root exudates, which are used by bacteria as a source of nutrients, helping their fixation on the roots and providing a selective advantage in the bacterial colonization and survival (Kloepper, 1985).The application of rhizobacteria for nematode control by treating seeds with bacterial suspensions presents high potential to improve growth and biological control.

Despite higher doses of urea did not affect plant fresh weight, the direct effect of $\mathrm{N}$ application may have promoted a negative effect on to the nematodes. The adverse effect of urea on phytonematodes has been attributed to the release of ammonia in the soil following urease activity. According to Silva et al. (2006), the ammonia $\left(\mathrm{NH}_{3}\right)$ released from the transformation of ammonium $\left(\mathrm{NH}_{4}\right)$ in the soil may selectively affect nematode populations. Spiegel et al. (1987) reported that ammonia acts as a plasmolyzing agent in second-stage juveniles of Meloidogyne.

Sudirman and Webster (1995) indicated that some concentrations of ammonia decrease the rate of juvenile hatching, acting directly as a nematode control through its toxic properties. According to the authors high doses of nitrogen are required for a satisfactory control of nematodes. However, the accumulation of nitrate and ammonia nitrogen in the soil may per se also be phytotoxic (Huebner et al., 1983).

In the present work, any beneficial effect of rhizobacterial inoculation, application of urea or a combination of both on the number of M. javanica eggs and juveniles or on the development of the plants were not observed. This lack of effect may be related to the fact that the bacteria were isolated from banana trees rhizospheres 
(Ribeiro et al., 2012). There is evidence of specificity between rhizobacterial isolates and host plant species (Coelho et al., 2007). Variations in the chemical composition of root exudates from different species, as well as from different cultivars and genotypes, have been reported (Baldani \& Dbereiner, 1981).

There have been no previous studies on the effect of a combination of nitrogen fertilizers and rhizobacteria for nematode control in common bean. However, such studies have been carried out in other crops. A study performed by Sidiqqi et al. (2001) showed that $P$. fluorescens isolates in combination with diammonium phosphate and urea promoted significant reductions in the numbers of $M$. incognita galls. Sharifi (2012) observed increased growth, dry weight, and seed yield in safflower (Carthamus tinctorius) when seeds were inoculated before planting with Pseudomonas strain 186.

Factors such as $\mathrm{pH}$, humidity, and $\mathrm{NH}_{4}{ }^{+}$concentration in the soil solution are directly associated with $\mathrm{NH}_{3}$ losses by volatilization. In the present study, the soil $\mathrm{pH}$ of 7.3 may have contributed to an accelerated volatilization process. In alkaline soils, $\mathrm{NH}_{4}{ }^{+}$ions present in the soil solution bind to $\mathrm{OH}^{-}$, resulting in the formation of $\mathrm{NH}_{3}$, which is highly volatile, especially when applied to sandy soils with low cation exchange capacity and high $\mathrm{pH}$ (Mattos-Junior et al., 2002).

The application of $50 \mathrm{~kg} / \mathrm{ha} \mathrm{N}$ for the common bean crop associated with B. pumilus-60, B. subtilis-34, and B. pumilus-1 isolates gave promising results regarding the reduction in number of $M$. javanica egg masses and galls, and could potentially be used for nematode control. This suppression effect was also observed at higher $\mathrm{N}$ doses; however, the increased production costs involved could render the use of such doses economically impracticable.

Finally, our study shows that the combined use of seed treatment with rhizobacteria and application of nitrogen fertilizers to the soil could potentially be used for the biological control of nematodes in common bean varieties showing low or no resistance to M. javanica, and taking into account the limitations associated with the use of chemical controls.

\section{Acknowledgements}

The authors gratefully acknowledge the financial support for conducting this study provided by FAPEMIG (Research Support Foundation of Minas Gerias). "This syudy was financed in part by the Coordenação de Aperfeiçoamento de Pessoal de Nível Superior-Brasil (CAPES)-Finance Code 001”.

\section{References}

Agudelo, F. V. (1980). Nematodes. In H. F. Schwartz, \& G. E. Galvez (Eds.), Bean production problems: Disease insect, soil and climatic constraints of Phaseolus vulgaris (pp. 315-326). Cali: CIAT.

Baldani, J. I., Pereira, P. A. A., Rocha, R. E. M., \& Dóbereiner, J. (1981). Especificidade na infecção de raizes por Azospirillum spp em plantas com via fotossintética C3 e C4. Pesquisa Agropecuária Brasileira, 16(3), 325-330.

Bonetti, J. I. S., \& Ferraz, S. (1981). Modificações do método de Hussey e Barker para extração de ovos de Meloidogyne exígua em raízes de cafeeiro. Fitopatologia Brasileira, 6(3), 553.

Campos, H. D., Campos, V. P., \& Coimbra, J. L. (2006). Efeito de exsudato radicular de Brachiaria decumbens e do Sorgoleone de Sorghum bicolor no desenvolvimento de Meloidogyne javanica. Nematologia Brasileira, $30(1), 59-65$.

Chun, S. C., Schneider, R. W., \& Cohn, M. A. (1997). Sodium hypochlorite: Effect of solution pH on rice seed disinfestation and its direct effect on seedling growth. Plant Disease, 81(7), 821-824. https://doi.org/ 10.1094/PDIS.1997.81.7.821

Coelho, L. F., Freitas, S. S., Melo, A. M. T., \& Ambrosano, G. M. B. (2007). Interação de bactérias fluorescentes do gênero Pseudomonas e de Bacillus spp. com a rizosfera de diferentes plantas. Revista Brasileira de Ciência do Solo, 31(6), 1413-1420. https://doi.org/10.1590/S0100-06832007000600018

Corrêa, B. O., Moura, A. B., Gomes, C. B., Somavilla, L., Rocha, D. J. A., \& Antunes, I. F. (2012). Potencial da microbiolização de sementes de feijão com rizobactérias para o controle de nematoide das galhas. Nematropica, 42(2), 343-350.

Dawar, S., Tariq, M., \& Zaki, M. J. (2008). Application of Bacillus species in control of Meloidogyne javanica (TREUB) Chitwood on cowpea and mash bean. Pakistan Journal of Botany, 40(1), 439-444.

Ferreira, D. F. (2011). SISVAR: A computer statistical analysis system. Ciência e Agrotecnologia, 35, 1039-1042. https://doi.org/10.1590/S1413-70542011000600001 
Huebner, R. A., Rodriguez-Kabana, R., \& Patternson, R. M. (1983). Hemicellulosic waste and urea for control of plant parasitic nematodes: Efect on soil enzyme activities. Nematropica, 13(1), 37-54.

IBGE (Instituto Brasileiro De Geografia E Estatística). (2014). Levantamento sistemático da produção agrícola (LSPA, 2014). Rio de Janeiro: IBGE. Retrieved July, 14, 2014, from http://www.ibge.gov.br

Jenkins, W. R. (1964). A rapid centrifugal-flotation technique for separating nematodes from soil. Plant Disease Reporter, 48, 692.

Khan, H. Z., Nadeem, M., Iqbal, S., Akbar, N., \& Iqbal, A. (2013). Response of spring maize (Zea mays L.) to integrated nitrogen management. Crop \& Environment, 4(1), 6-10.

Kloepper, J. W., Scher, F. M., Laliberté, M., \& Zaleska, I. (1985). Measuring the spermosphere colonizing capacity of bacterial inoculants. Journal of Microbiology, 31(10), 926-929.

Lian, L. H., Tian, B. Y., Xiong, R., Zhu, M. Z., Xu, J., \& Zhang, K. Q. (2007). Proteases from Bacillus: A new insight into the mechanism of action for rhizobacterial suppression of nematode populations. Letters in Applied Microbiology, 45(3), 262-269. https://doi.org/10.1111/j.1472-765X.2007.02184.X

Ludwig, J., Moura, A. B., \& Gomes, C. B. (2013). Potencial da microbiolização de sementes de arroz com rizobactérias para o biocontrole do nematoide das galhas. Tropical Plant Pathology, 38(3), 264-268. https://doi.org/10.1590/S1982-56762013005000007

Mattos-Junior, D., Cantarella, H., \& Quaggio, J. A. (2002). Perdas por volatilização do nitrogênio fertilizante aplicado em pomares de citros. Revista Técnico-Científica de Citricultura: Laranja, 23(1), 263-270.

Naue, C. R., Rocha, D. J. A., \& Moura, A. B. (2014). Biological control of tomato bacterial spot by seed microbiolization. Tropical Plant Pathology, 39(5), 413-416. https://doi.org/10.1590/S1982-56762014000 500009

Oostendorp, M., \& Sikora, R. A. (1990). In-vitro interrelationships between rhizosphere bacteria and Heterodera schachtii. Revue de Nématologie, 13(3), 269-274.

Pedrosa, E. M. R., Moura, R. M., \& Silva, E. G. (2000). Respostas de genótipos de Phaseolus vulgaris a meloidoginoses e alguns mecanismos envolvidos na reação. Fitopatologia Brasileira, 25(2), 190-196.

Ribeiro, A. C., Guimarães, P. T. G., \& Alvarez, V. H. (1999). Recomendações para o uso de corretivos e fertilizantes em Minas Gerais (5a aproximação, p. 359). Viçosa, MG: Comissão de Fertilidade do Solo do Estado de Minas Gerais.

Ribeiro, R. C. F., Campos, V. P., Xavier, A. A., Rocha, L. S., Ribeiro, H. B., Aguiar, F. M., ... Dias-Arieira, C. R. (2012). Rizobactérias no controle de Meloidogyne javanica e mal do panamá em bananeira. Nematropica, 42(1), 218-226.

Sanhueza, R. M. V. B., \& Melo, I. S. (2007). Identificação de bactérias por análise dos ácidos graxos. In R. M. V. B. Sanhueza, \& I. S. Melo (Eds.), Métodos utilizados no biocontrole de fitopatógenos (pp. 59-65). Bento Gonçalves: Embrapa Uva e Vinho.

SAS Institute. (2000). SAS/STAT User's Guide, Version 8 (p. 1383). Cary.

Siddiqui, Z. A., Iqbal, A., \& Mahmood, I. (2001). Effects of Pseudomonas fluorescens and fertlizers on the reproduction of Meloidogyne incognita and growth of tomato. Applied Soil Ecology, 16(2), 179-185. https://doi.org/10.1016/S0929-1393(00)00083-4

Silva, V. N., Silva, L. E. S. F., \& Figueiredo, M. V. B. (2006). Co-inoculação de sementes de caupi com Bradyrhizobium e Paenibacillus e sua eficiência na absorção de cálcio, ferro e fósforo pela planta. Pesquisa Agropecuária Tropical, 36(2), 95-99.

Simão, G., Homechin, M., Santiago, D. C., Silva, R. T. V., \& Ribeiro, E. R. (2005). Comportamento de duas cultivares de feijoeiro em relação à Meloidogyne incognita. Ciência Rural, 35(2), 266-270. https://doi.org/ $10.1590 / \mathrm{S} 0103-84782005000200003$

Soares, A. L. L., Ferreira, P. A. A., Pereira, J. P. A. R., Vale, H. M. M., Lima, A. S., Andrade, M. J. B., \& Moreira, F. M. S. (2006). Eficiência agronômica de rizóbios selecionados e diversidade de populações nativas nodulíferas em perdões (MG). II-feijoeiro. Revista Brasileira Ciências do Solo, 30(5), 803-811. https://doi.org/10.1590/S0100-06832006000500006

Spiegel, Y., Chet, I., \& Cohen, E. (1987). Use of chitin for controlling plant parasitic nematodes. II. Mode of action. Plant and Soil, 98(3), 337-345. https://doi.org/10.1007/BF02378355 
Sudirman, N. A., \& Webster, J. M. (1995). Effect of ammonium ions on egg hatching and second-stage juveniles of Meloidogyne incognita in axenic tomato root culture. Journal of Nematology, 27(3), 346-352.

\section{Copyrights}

Copyright for this article is retained by the author(s), with first publication rights granted to the journal.

This is an open-access article distributed under the terms and conditions of the Creative Commons Attribution license (http://creativecommons.org/licenses/by/4.0/). 